\title{
Nyt lys over de slesvigske byers forfatningspetitioner 1816-17
}

Af G. Japsen.

I Rigsarkivet opbevares en række petitioner, som i vinteren 1816-17 indgik fra de fleste slesvigske købstæders bykollegier, og hvori disse bad om, at Slesvig måtte få en forfatning. Anleduingen til petitionernes indsendelse var, at der kort tid forinden var blevet nedsat en kommission, der skulle udarbejde forslag til en forfatning for Holsten.

Petitionerne fremkaldte ikke noget svar fra regeringens side, og da alle byer slog sig til ro med dette, er det ikke mærkeligt, at petitionerne blev glemt, både af den store offentlighed og af historieforskningen. En forandring indtrådte først, efter at Anton Springer i 1870, i 1. del af sin store Dahlmann-biografi, havde gjort gældende, at det var den liberale professor Dahlmann i Kiel - der tillige var det slesvigholstenske ridderskabs sekretær som havde fremkaldt den slesvigske petitionsbevægelse. Som mellemmand mellem Dahlmann og købstæderne nævnede Springer Åbenrås borgmester, Bendix Schow. Det lå nu nær at vurdere petitionerne som et tidligt udslag af tyskorienteret slesvigholstenisme og at opfatte Dahlmann som den vidtskuende politiske strateg, der rejste både adel og borgerskab til kamp for Hertugdømmernes tyskhed. ${ }^{1}$

Det kan derfor ikke undre, at en række danske og tyske historikere herefter tog de slesvigske forfatningspetitioner op til behandling. A. D. Jørgensen (i 6 . bind af Danmarks Riges Historie) og efter ham Hans Jensen (i 1 . bind af De danske Stænderforsamlingers Historie) opfattede byernes ønske om en forfatning som hovedsageligt økonomisk motiveret. I 1937 gennemgik Knud Fabricius i 4 . bind af Sønderjyllands Historie som den forste omhyggeligt petitionernes indhold; han understregede deres betydning 
og gjorde et lidet overbevisende forsøg på at inddele dem i to kategorier, alt efter som de udgik fra tidligere gottorpske eller kongelige byer. Den nazistisk inspirerede historiker John Boyens gav petitionerne en hovedplads i sin bog fra 1944, "Politische Petitionen und Petitionsbewegung im schleswig-holsteinischen Verfassungskampf. F. Chr. Dahlmann bis Uwe Jens Lornsen (1815-30) «. Han fremstillede petitionerne som udtryk for en protysk og bevidst antidansk folkebevægelse. Boyens' af forudindtagne meninger prægede tolkning blev uden vanskelighed sat på plads af professor Alexander Scharff i dennes roligt og nøgternt argumenterende afhandling fra 1957 »Zur Beurteilung der Petitionsbewegung 1816-1818", hvori han understregede, at forfatningsbevægelsen ikke var en »tysk bevægelse", men et udslag af den alment vesteuropæiske liberalisme.

Den nyeste behandling af de slesvigske forfatningspetitioner er givet af Christian Degn i 6. bind af Geschichte Schleswig-Holsteins (1960). Han når frem til en opfattelse, der er meget nær ved A. D. Jørgensens, og det er bemærkelsesværdigt, at ikke blot Dahlmann, men også Falck hos ham omtales som initiativtagere — åbenbart, fordi der spores så grumme lidt af Dahlmanns ånd i petitionerne.

Fælles for alle hidtidige vurderinger af petitionsbevægelsen har været, at historikerne med hensyn til det væsentlige spørgsmål om petitionernes ophavsmand har været henvist til den fremstilling, som Springer giver i sin Dahlmann-biografi. Det hedder dér, ${ }^{2}$ at Dahlmann var klar over, at den offentlige mening måtte vindes, hvis ridderskabets forfatningsbestræbelser skulle vinde sejr. Et forsøg på at få de godsejere, der stod uden for det privilegerede ridderskabs rækker, til at deltage i kampen, måtte opgives, da kongen forbød godsejernes møder. Springer fortsætter nu således:

„Så meget des kraftigere måtte agitationen fremmes $i$ byerne, især i de slesvigske. Ridderskabet skulle ikke tro, at det stod forladt i kampen mod regeringen, og på den anden side syntes det tilrådeligt stedse at minde det om, at det ikke var nok, at dets privilegier blev genoprettet, men at det eneste, der kunne tilfredsstille, var en almindelig landsforfatning. Også her lod Dahlmann det ikke mangle på gode råd. Han satte sig i forbindelse med byernes tillidsmænd, f. eks. med justitsråd Schow i Åbenrå, og for- 


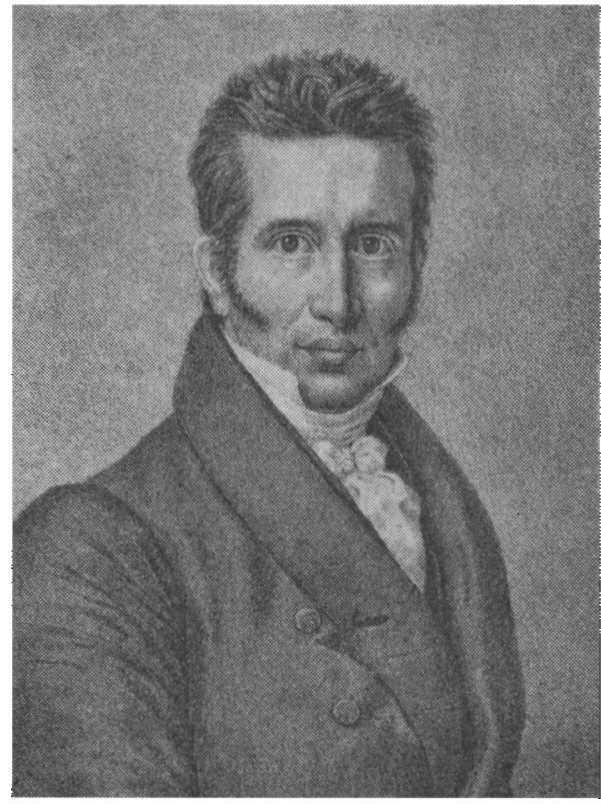

Friedrich Christoph Dahlmann, $1785-1860$, professor $i$ Kiel.

lattede forslagene til byernes petitioner, snart opmuntrede han, og snart formanede han til forsigtighed for ikke at tirre regeringen til magtanvendelse ${ }^{3}$ eller bringe ridderskabet i forlegenhed, eftersom han, den afhængige embedsmand, ikke måtte handle $i$ dets navn eller skubbe ansvaret for sine råd og handlinger over på det. Personligt havde han gerne set, at deputationen havde meddelt byerne alle retshævdende dokumenter, og at den til kongen rettede anmodning om udstedelse af en fælles forfatning for de to hertugdømmer også var blevet underskrevet af byernes repræsentanter. Dermed ville man have udtalt en anerkendelse af byerne ${ }^{4}$ som en medberettiget stand, hvis ret kun hvilede. Alligevel advarede Dahlmann mod dette skridt, der blev anbefalet $i$ byernes kreds. I deputationen sad der kun holstenere, og enhver tilnærmelse fra disses side til de slesvigske byer ville have fremkaldt mistanke om, at den ville drage Slesvig ind $i$ sin interesse, og skadet i København".

Hvad spørgsmålet om petitionernes tilblivelse angår, er man imidlertid ikke længere henvist til at bygge på Springers fremstilling alene. I Dahlmanns privatarkiv, der nu befinder sig i 
Deutsche Staatsbibliothek i Østberlin, opbevares nemlig de breve, som borgmester Bendix Schow i Ảbenrå 1816-17 sendte til Dahlmann $i$ anledning af forfatningssagen. ${ }^{5}$

Før vi går over til en gennemgang af dette brevstof, er det rimeligt at give et rids af ridderskabets konflikt med regeringen, af Dahlmanns plads $i$ denne konflikt og af hans politiske anskuelser.

Friedrich Christoph Dahlmann (1785-1860) var født i det dengang svenske Wismar. Mange bånd knyttede ham til Holsten. Hans morbroder, F. C. Jensen, havde således $\mathrm{i}$ mange år været det slesvigholstenske ridderskabs sekretær, før han blev deputeret i det Tyske Kancelli. Endvidere blev Dahlmann i 1817 gift med Julie Hegewisch, en datter af professor D. H. Hegewisch, der var hans forgænger som historieprofessor i Kiel og i 1797, sammen med F. C. Jensen, havde udgivet ridderskabets privilegier. Hans ungdomsår er præget af den politiske brydningstid, han levede i. Han svinger flere gange fra kosmopolitisme til tysk nationalromantik, og først $i$ årene efter 1815 udformes grundtrækkene $i$ hans politiske anskuelser definitivt. Han opholdt sig i flere perioder i København, og da de politiske forhold vanskeliggjorde hans forbliven i Napoleontidens Tyskland, opgav han kampen mod fremmedstyret og besluttede at skabe sig en karriere i Danmark. I 1811 blev han dansk statsborger, holdt forelæsninger på Københavns universitet (på latin), stiftede bekendtskab med dansk litteratur (han var bl. a. gæst i Bakkehuset) og skrev i 1812 en lille bog om Oehlenschlägers dramatiske værker. Samme år blev han, takket være morbroderen, knyttet til universitetet i Kiel, hvor han 1813 blev professor i historie. I Kiel oplevede han det danske monarkis dybe fald (statsbankerotten i 1813, de allierede troppers besættelse af Holsten og tabet af Norge i 1814). Herfra fulgte han den tyske rejsning mod Napoleon og tilsluttede sig den sværmeriske tro på folkefrihedens sejr $i$ et stort tysk rige. Nu brød en glødende tysk nationalisme, gennemtrængt af romantikkens forestillinger om oldgermansk frihed og folkeåndens historieskabende kraft igennem hos denne mørke og stejle, men samtidig virkelystne mand.

I marts 1814 nedfældede han de politiske tanker, der dengang fyldte ham, i skriftet „Uber die letzten Schicksale der deutschen 
Untertanen Dänemarks und ihre Hoffnungen auf die Zukunft", som han dog aldrig offentliggjorde. Det genspejler tydeligt de tysknationale kredses højspændte forventninger efter Napoleons fald: ikke alene skal Holsten igen være en del af Tyskland, også det forbundne Slesvig bør optages i det tyske rige.

I juli 1815 holdt Dahlmann på Kiels universitet en festtale, fyldt af høj patos, $i$ anledning af sejren ved Waterloo. Glæden over denne sejr bør føles i begge hertugdømmer, sagde han, thi „selv om slesvigeren aldrig har været $i$ det tyske forbund, så tilhørte han det og tilhører han det fortsat gennem sin broder holsteneren".

Kort tid efter offentliggjorde han $i$ 1. årgang af de kielske forfatningsvenners tidsskrift „Kieler Blätter“, som han var medudgiver af, sin berømte artikel „Ein Wort über Verfassung“. Han onsker en lovgivende forsamling, men er modstander af demokrati: „Det er forfatningernes kunst at få folkets bedre del til at tale“. Han hævder, at slesvig-holstenerne har et retsligt krav på en forfatning, og at forbindelsen mellem de to hertugdømmer er "den største af alle deres forrettigheder og friheder". Kravet om Slesvigs optagelse $i$ det tyske rige er forsvundet. I stedet hedder det, at Slesvig er ligesom broen, der forener holsteneren med danskeren. Landets første og værdigste mænd bør nu træde sammen og genopvække, hvad der slumrer. „Måtle vort fremtidige folkeliv selv skyde frem af den dybt erkendte fortid", hedder det $\mathrm{i}$ ægte romantisk ånd. Han afviser med foragt forfatninger som den franske af 1793 , der er „udgået af den blotte teori". Med denne faste og modige afhandling skabte Dahlmann sig både i Hertugdømmerne og i Tyskland et navn som en af forfatningspartiets førere.

På dette tidspunkt var Dahlmann blevet ridderskabets sekretær efter den i april 1815 afdøde professor Schrader. 4. juli samme år blev Dahlmann på den meget reaktionære og regeringsfjendtlige Fritz Reventlows forslag valgt til posten, og 18. august tillod kongen Dahlmann at modtage valget.

For ridderskabet var valget af den rette mand en sag af stor betydning, eftersom det lå $i$ heftig strid med regeringen om så vigtige sager som bekræftelsen af dets privilegier og indførelsen af en landdag; hertil kom ridderskabets stadige klager over den øko- 


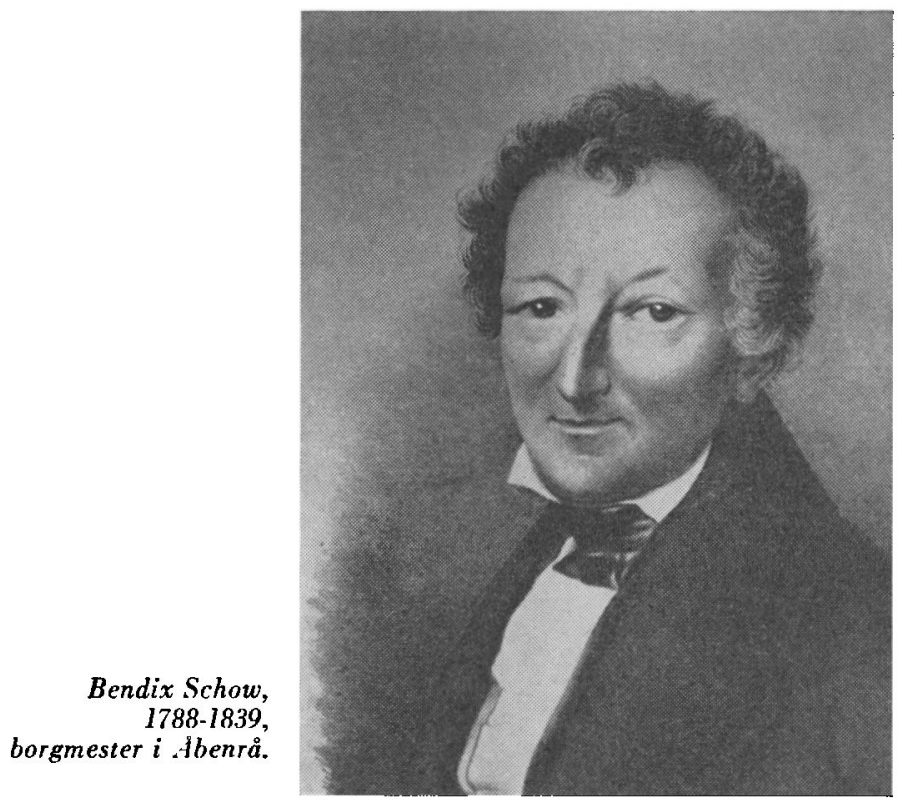

nomiske misere og specielt regeringens skattepålæg. Hvad Dahlmanns motiver til at antage valget angår, kan der næppe være tvivl om, at han i den tyske nationalromantiks ånd opfattede ridderskabets privilegier som en rest af fortidens folkerettigheder, og at kampen for en genoplivelse af privilegierne i deres gamle omfang af ham blev anset for den eneste rette vej frem til en lidssvarende forfatning (hvorved Dahlmann forstod en forfatning med en stærk kongemagt, et adelskammer og et kammer med repræsentation for den dannede del af borgerskabet).

Det er uvist, i hvor høj grad ridderskabets forskellige indlæg i striden dækker Dahlmanns opfattelse, men når man tager Dahlmanns principfasthed og ubøjelighed $i$ betragtning, er der ingen anledning til at antage uoverensstemmelser på betydningsfulde punkter, snarere tør man vel gå ud fra, at det med tiden var Dahlmanns meninger, der blev bestemmende. ${ }^{6}$

Ridderskabets (nye) konflikt med regeringen ${ }^{7}$ tog sin begyndelse med dets forestilling til kongen den 23. 1. 1815, hvori man tog de dårlige okonomiske forhold som anledning til at bede om en landdag for Holsten. Da kongen i slutningen af maj kom 
hjem fra Wienerkongressen, overrakte en ridderskabsdeputation ham i Slesvig en ny forestilling, der satte onsket om en forfatning - nu for begge hertugdømmer! - på førstepladsen. Den 22. 8. 1815 fulgte en tredje forestilling fra ridderskabet. Heri betonede man, at forbindelsen mellem hertugdømmerne var det første af privilegierne. I denne understregning af forbindelsen mellem Holsten og Slesvig er det rimeligt at se et tegn på Dahlmanns virksomhed som ridderskabssekretær.

Imidlertid påvirkedes ridderskabets holdning i disse sommermåneder stærkt af undertegnelsen af den tyske Bundesacte den 8. juni; i dennes $\S \mathbf{1 3}$ lovedes der hvert et af de tyske forbundslande en stænderforfatning. Den 6 . september bestemte en kongelig resolution, at Holsten ville få en forfatning i henhold til denne paragraf, men at det slesvigske og det holstenske ridderskabs gamle forbindelse (nexus socialis) fortsat måte bestå.

Et halvt års tid senere (februar 1816) udkom Falcks kendte og for slesvigholstenismens teori grundlæggende bog „Das Herzogthum Schleswig in seinem gegenwärtigen Verhältniss zu dem Königreich Dänemark und zu dem Herzogthum Holstein“, i hvilken han søgte at bevise, at kongeloven ikke gjaldt i Sønderjylland, og at den gamle forfatning derfor måtte anses for bestående ikke alene i Holsten, men også i Slesvig.

Regeringen fulgte imidlertid roligt sin kurs, og den 19. august 1816 udstedtes en kongelig kundgørelse om, at en kommission den 4. november skulle træde sammen $i$ København for at udarbejde forslag til en forfatning for Holsten. To dage forinden havde kongen omsider stadfæstet ridderskabets privilegier, men i to eksemplarer, ét for det slesvigske og ét for det holstenske ridderskab, og i det forstnævnte var der taget det væsentlige forbehold: „forsåvidt sådanne (privilegier) ikke er i modstrid med vor suveræne eneregering over nævnte hertugdømme".

Fra denne skildring af de forfatningsbestræbelser, i hvilke Dahlmann spiller en fremtrædende rolle, må vi vende os til Ảbenrås borgmester, Bendix Franz Ludewig Schow (1788-1839). Han var født i Rendsborg som søn af en dansk officer, der var blevet stationeret i Hertugdømmerne. Bornene blev, med undtagelse af Bendix, officerer eller gift med officerer. Bendix gik en anden vej; han studerede jura $i \mathrm{Kiel}$, blev volontør i rente- 
kammeret og var så $i$ tre år ansat $i$ Tyske Kancelli. 1805 blev han borgmester $\mathrm{i}$ Åbenrå og viste sig $\mathrm{i}$ denne stilling at være en samvittighedsfuld og dygtig embedsmand. På grund af sine fortjenester blev han i 1815 udnævnt til justitsråd. Hans hustru var en datter af generalsuperintendenten for Holsten, J. L. Callisen. Bendix Schow hørte hjemme i et typisk borgerligt embedsmandsmilieu, hvor hengivenhed for helstaten og monarken var en selvfølge. Som repræsentant for en købstad måtte han samtidig forsvare de førende borgerkredses interesser over for centraladministrationen, og herfra var der, under de givne betingelser, kun kort vej til at ønske indførelse af en stænderforsamling, hvor byernes stemme kunne lade sig høre. Det vides, at man med begejstring læste „Kieler Blätter" i Schows hjem, og at Ernst Moritz Arndts napoleonfjendske og samfundskritiske skrifter fandtes $i$ hans bibliotek. Der haves derimod ingen oplysninger om, hvordan han kom $i$ forbindelse med Dahlmann, hvem han $i$ brevene fra 1816-17 kalder sin kære eller dyrebare ven. Fra 1816 til 1818 tog han virksom del i forfatningssagen i Hertugdømmerne. I 1830 blev han mistænkt for indirekte at have stottet den Lornsen'ske aktion, og fra Kiel opfordrede man ham - forgæeves - til at tage initiativet til en ny forfatningspetition. Han betegnedes da som "en $i$ sandhed liberal borgmester med patriotisk indstilling."

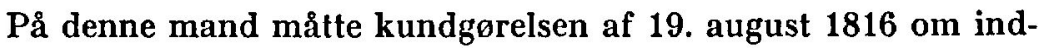
kaldelse af en forfatningskommission for Holsten naturligvis virke stærkt. Det afgørende skridt var taget; nu gjaldt det om også at skaffe Slesvig en forfatning, mente han. Ud fra denne opfattelse henvendte Schow sig den 22. september til sin ven Dahlmann for at få ridderskabet til at tage sagen op sammen med de slesvigske byer. Alle venter nu af ridderskabet - skriver han - at det som rest af de tidligere stænder på det kraftigste vil forsvare disses rettigheder. "Men for at ridderskabet ikke skal tro, at det kommer til at stå forladt, så kan jeg på forhånd forsikre, at mange af byerne kun venter på en impuls fra ridderskabets side for at tilslutte sig det. Ville det derfor ikke være gavnligt og svarende til sagen, hvis ridderskabet $i$ en $i$ ærbødige udtryk affattet forestilling bad kongen om, at hertugdømmet Slesvig også måtte få en forfatning «. Man skulle kort komme ind på Slesvigs ret til en forfatning, men samtidig vise, "at det ikke er herdugdømmets ind- 
byggeres hensigt derfor at slutte sig til Tyskland og til det Tyske Forbund, men at en forfatning er uomgængelig nødvendig for hertugdømmets vel og til opretholdelse af dets kredit, samt at forholdet mellem de to hertugdømmer, som har haft så velsignelsesrige følger for begge $i$ så mange århundreder, ville blive fuldstændig sønderrevet, hvis det ene af hertugdømmerne fik del $i$ en forfatnings velgerninger, men ikke det andet. Denne bemærkning fremsætter jeg, fordi kongen, især af politiske grunde, er bange for at give hertugdømmet Slesvig en forfatning, idet han tror, at han derved indrømmer de udenlandske magter en større indflydelse på sine øvrige stater «. Ansøgningen fra ridderskabet s måtte af dette meddeles byerne som den bestående medberettigede stand, og disse spørges, om de agtede at underskrive den. Hertil vil mindst $2 / 3$ af købstæderne være rede. For sagen er allerede vundet: Flensborg, Husum, Sønderborg, Haderslev og Åbenrå; der kan ikke tvivles om, at Eckernförde og Tönning vil tiltræde; stemningen i byerne Tønder, Frederiksstad, Garding og Burg på Femern er jeg i tvivl om, og der tør vel ikke tænkes på et godt resultat i byen Slesvig. Hvis ridderskabet imidlertid ikke skulle være indforstået med at meddele ansøgningen, så bør byerne opfordres til at give ridderskabet en fuldmagt, hvorefter det $i$ byernes navn tager sig af den fælles sag hos regeringen. Jeg frygter imidlertid for, at $i$ sidstnæunte tilfælde vil den gamle, endnu ikke slukte mistillid igen røre på sig, som om ridderskabet søgte at opnå noget på byernes bekostning ". Hvis Dahlmann anser disse forslag for passende og realisable, fortsatte Schow, bedes han bringe dem på bane på ridderskabets forestående møde under mikkelsdagsmarkedet.

Af dette brev, hvis vigtigste partier er gengivet $\mathrm{i}$ ordret oversættelse, fremgår med al tydelighed, at Springer ikke har ret, når han siger, at det var Dahlmann, som, for at vinde den offentlige mening, satte sig i forbindelse med Schow. Det var tværtimod den sidstnævnte, som efter et forarbejde, hvorunder to tredjedele af byerne var vundet for hans plan, foreslog Dahlmann en alliance mellem ridderskab og købstæder til opnåelse af en slesvigsk forfatning. Et andet slående eksempel på Springers vilkårlige behandling af Schows breve er sætningen om, at ridderskabet ikke skulle tro, at det stod forladt $i$ kampen mod rege- 
ringen; den fremtræder hos Springer som udtryk for Dahlmanns tankegang, mens det af Schows brev ses, at det er byerne, der med disse ord tilbyder at støtte ridderskabet, såfremt det vil optage kampen for en slesvigsk forfatning.

På sit møde under mikkelsdagsmarkedet vedtog ridderskabet en forestilling til kongen, der er dateret 8. oktober 1816. Den kraft og veltalenhed, der præger den, peger hen på Dahlmann som lorfatteren. Så meget mere påfaldende er det, at den kun på et enkelt og underordnet punkt (afvisningen af mulig tysk indblanding) tager hensyn til Schows ønsker. Det hedder $\mathrm{i}$ henvendelsen, at tavsheden om Slesvigs forfatningsforhold har vakt stor uro i begge hertugdømmer og „såvel fra slesvigere og holstenere er der, mundtligt og skriftligt, tilgået os opfordringer om endelig ikke at lade noget ude af betragtning, som $i$ denne henseende kunne fore til snarlig sikkerhed". Forestillingen rummer iøvrigt en sådan lovprisning af hertugdømmernes gamle fallesskab, at eftertiden heri har set programmet for det kommende slesvig-holstenske parti. Det var alt, hvad ridderskabet (og Dahlmann) ville gøre til støtte for de slesvigske forfatningsønsker.

Den 22. september havde Schow fuld af iver sendt sit brev til Dahlmann, men der gik hele to måneder, før han (den 22. november) modtog Dahlmanns svar. Ridderskabets forestilling af 8 . oktober kendte han allerede $\mathrm{i}$ afskrift. Denne forestilling var i sig selv egnet til at nedslå Schows forhåbninger, og Dahlmanns langvarige tavshed må have overbevist ham om, at ridderskabets dør var lukket. Nu modtog han i Dahlmanns brev af 11 . november (med tilføjelser af 18. november) en slags forklaring på, hvorfor byernes forslag var blevet afvist. Schow svarede den 1 . december: „De, højtærede ven, er af den mening, at en tilnærmelse fra ridderskabets side til byerne ville være mislig, fordi dette altid ville blive betragtet som et forsøg fra holstenernes side på at drage Slesvig med ind i deres interesse". Heroverfor henviste Schow til, at ridderskabet havde mange slesvigske medlemmer. Schow troede heller ikke, at sagen ville strande på enkelte magistraters slethed (,thi selv de medlemmer af magistraten i Flensborg f. eks., som er mod sagen, har kun en forskellig opfattelse, men ville aldrig gribe til skændige forholdsregler for at forpurre sagen"). Han fortsatte med nogen skarphed: „Ligeledes forekommer det 
mig, at enkelte medlemmer af ridderskabet og selv De som deputationssekretær har fået opfordringer nok til at bygge videre på dem“. Som sagen lå, kunne disse opfordringer ikke være officielle, men opfordringen fra Schow var „den udtrykkelige følge af en aftale mellem embedsmændene $i$ forskellige byer". Han tog også Dahlmann ilde op, at denne havde bebrejdet slesvigerne, at der endnu ikke var flydt et frimodigt ord fra deres pen.

Dahlmanns motivering for afvisningen af byernes plan (den ville fremkalde mistanke om, at ridderskabet ville drage Slesvig med ind $i$ sin interesse) er så tynd, at Ostenfeld ${ }^{8}$ med rette har kommenteret den således: > Når deputationen stadig talte om Hertugdømmerne, og ikke om Holsten, lå deri dog tydeligt nok, at den søgte at drage Slesvig ind $i$ sin interesse, så det kunne ikke være skjult for regeringen, og Dahlmann nærede, efter hvad Springer selv anfører, I, s. 133, ikke nogen overdreven ængstelse for at vække mishag $\mathrm{i}$ København. Hvis han altså virkelig frarådede et samarbejde mellem byerne og deputationen, har han handlet ud fra sit aristokratiske synspunkt."

Den kreds af liberale embedsmænd, hvis ordfører Schow var, havde imidlertid ikke opgivet ævred, fordi de mødte en kold skulder hos ridderskabet. „Nu, da ridderskabet ikke vil tage et skridt fremad, er for frygtsomt eller for stolt ${ }^{*}$, hedder det $\mathrm{i}$ brevet af 1 . december, vil de enkelte byer sandsynligvis indsende forestillinger til regeringen. „Så snart Flensborg bare vil være med, vil sikkert et betydeligt antal af de øvrige byer gøre det samme. For der imidlertid sker noget, vil jeg skrive til gehejmeråd Brockdorff $i$ København og bede om hans opfattelse $i$ denne sag".

$\mathrm{Nu}$ kom begivenhederne virkelig i skred. Allerede den 9. december sendte Schow et nyt brev til Dahlmann, der havde reageret meget hurtigt på Schows tilrettevisende ord og sendt en korrektion af sin undskyldning for afvisningen af byerne: han havde ikke talt om ridderskabet som sådant, men om dets deputation, hvori der kun var holstenere. Denne nye forklaring gik Schow let hen over, og han viste heller ingen begejstring for et forslag fra Dahlmann om, at byerne skulle sende ridderskabet meddelelse om deres skridt $\mathbf{i}$ forfatningssagen. Schow ønskede $\mathbf{i}$ stedet, at der $\mathbf{i}$ den af Dahlmann foreslåede skrivelse til ridderskabet 
(han regnede kun med, at Ảbenrå, Haderslev og Eckernförde ville underskrive en sådan) "kort skulle siges, at byerne havde indgivet eller ville indgive ansøgninger, samt at de havde hørt, at ridderskabet havde taget et lignende skridt, og bad det om meddelelse af dets vigtigste indlæg $\mathrm{i}$ denne henseende, og hvad fremtiden angår, anmodede om, at man, hvis lignende skridt skulle være nødvendige, ville tage byerne med“. (Schows sprog var, som man ser, overmåde knudret). Det fremgår ikke af brevene, hvordan Dahlmann har stillet sig til dette modforslag.

Det, der først og fremmest optog Schow, var imidlertid det svar, han havde modtaget på sin henvendelse til baron Brockdorff, der var kansler for Holsten og nu, som medlem af forfatningskommissionen, opholdt sig i København. Dahlmann havde ikke ventet noget godt fra den kant, men "svaret er faldet over al forventning gunstigt ud“. Her er, hvad Brockdorff skrev til Schow den 7. december:

„Naturligvis er hertugdømmet Slesvig, og først og fremmest byerne meget væsentligt interesseret $\mathbf{i}$ det, hvis kun Holsten alene får en stændersk forfatning. Hidtil har det hverken været kongens eller statsrådets mening at give hertugdømmet Slesvig en konstitution, og jeg tvivler om, at der vil blive taget hensyn til en bys ønske. Hvis en sådan ansøgning kun indkom fra én magistrat, ville dette ikke netop tjene som anbefaling. Kun hvis byernes flertal hver for sig indsendte ansøgninger, ville denne betragtning forsvinde. Tendensen skulle ikke så meget gå ud på en retsdeduktion som på at vise de store ulemper, som Slesvig måtte frygte gennem separationen og udstedelsen af en konstitution for Holsten. Hertil måtte regnes, at $\mathbf{i}$ samme forhold som kreditten $\mathbf{i}$ Holsten ville tiltage gennem indførelsen af en stændersk forfatning, målte den aftage $i$ det slesvigske, så at Holstens flor blev bygget på Slesvigs bekostning, at Slesvig efter separationen ville stå $\mathbf{i}$ fare for at miste de rettigheder, som det ellers havde haft $\mathbf{i}$ Hamborg p.p. som følge af sin forbindelse med Holsten, at det, forbundet med Holsten, kunne have al mulig nytte af det Tyske Forbund uden at tage del $i$ byrderne, at den tidligere forbindelse aldrig havde haft tysk indblanding i de slesvigske anliggender til følge, og at der følgelig heller ikke nu var grund til at frygte noget ufordelagtigt. Sådanne og lignende betragtninger 
ville man aldrig kunne tage ilde op. Men jeg ville også kun råde til at skrive $i$ en sådan ånd. Et gunstigt resultat kan jeg ikke stå inde for. Det er også svært for kongen at give Slesvig en forfatning og at nægte Danmark den. Dette rige tror at have lige så nære rettigheder, og frygter for ellers at blive fuldstændig afhængigt af Hertugdømmernes stænder".

Det er betegnende for ånden i den Schow'ske kreds af embedsmænd, at Dahlmanns hyldest til hertugdømmernes forening fik en kølig modtagelse hos Schow, medens han er begejstret for den konservative baron Brockdorffs nøgterne råd. Brockdorff taler, ligesom de, om en forfatning for Slesvig; de gamle „landsrettigheder" lægger han, ligesom de, kun ringe vægt på, og de kan også enes om først og fremmest at henvise de materielle ulemper, som de mener vil blive følgen, når Holsten, men ikke Slesvig får en forfatning.

Efter modtagelsen af Brockdorffs brev gik det hurtigt fremad med byernes selvstændige aktion. I sit brev af 9 . december fortalte Schow, at han straks den følgende dag ville rejse til Flensborg "for at virke så meget jeg kan“ (Haderslev havde allerede svaret gunstigt), og at han derpå ville opfordre Sønderborg, Tønder, Eckernförde og Husum. De sidstnævnte to sydslesvigske byer havde han åbenbart ingen sikker indflydelse på, og han bad derfor Dahlmann og hans kollega Twesten om „umiddelbart“ at påvirke dem. Inden en uge var gået, havde bykollegierne i Flensborg, Åbenrå, Haderslev, Tønder og Sønderborg givet deres tilslutning. „Retssynspunktet vil vi ikke sætte helt til side, men blot holde det $i$ baghånden som reserve og værn“. (Brev fra Schow af 15.12.).

Vanskeligere gik det med at opfylde Dahlmanns ønske om, at byerne skulle sende skrivelser til ridderskabet. Den eneste, han den 15. december havde fået et halvt tilsagn fra, var borgmester Ahlmann i Sønderborg, der ville komme ham i møde på halvvejen. Schow havde ikke kunnet få tilslutning til andet end en takkeskrivelse, til hvilken man skulle føje ønsket om, ,at vi i fremtiden måtte være berettigede" til at handle $\mathbf{i}$ fællesskab med ridderskabet. Af det brev, som Schow afsendte til Dahlmann den følgende dag (16. december), synes at fremgå, at magistraten i Åbenrå kun har sendt en ren takkeskrivelse.

Den 24. december indsendte Flensborg og Åbenrå deres forfat- 
ningspetitioner, og i de folgende uger fulgte de fleste andre byer efter.

Under omslaget i Kiel i januar 1817 har Schow sikkert, som bebudet $i$ et brev af 18. 12. 1816, fảet lejlighed til at tale personligt med Dahlmann om hele forfatningssagen. Den 5. marts 1817 sendte Dahlmann et nyt brev til Schow, som denne besvarede i en skrivelse af 23 . marts 1817 . Om petitionerne indeholder den kun følgende korte sætninger: „Fra amterne hører jeg ikke, at der gores noget for den fælles sag. Ogsà vi byboere er nu rolige og afventer forfatningsforslagets fremkomst". Brevet er imidlertid bemærkelsesværdigt ved at vise både, hvad der forbandt, og hvad der adskilte Schow og Dahlmann.

Schow gav atter udtryk for sin beundring for Dahlmann, „hvem jeg er hengiven med hele min sjæl“, og bad ham indtrængende om ikke at forlade landet, selv om han for tiden havde så megen modgang i forfatningssagen. Ligesom Dahlmann mente han, at adelen $i$ en monarkisk stat må stå som formidler mellem fyrste og folk a. Det, der bestemte Schows praktiske stillingtagen, var imidlertid ikke almene betragtninger, men de aktuelle opgaver, hvis losning trængte sig på. Dette kom klart til udtryk i de to mænds helt forskellige indstilling til ridderskabets beslutning om skattenægtelse.

Den 14. januar 1817 havde kongen afslået ridderskabets anmodning om at mâtte stille forslag om det skattebeløb, det mente at kunne påtage sig ud over den ordinære kontribution. Dermed havde regeringen tillige tilkendegivet, at ridderskabets privilegier ikke havde forfatningsmæssig betydning. I dette principspørgsmål måtte ridderskabet reagere kraftigt, og i en af Dahlmann forfattet forestilling af 27. januar 1817 påstod det, at skattebevillingsretten fortsat stod ved magt, og at man følgelig kun ville betale, hvis regeringen anerkendte denne ret som indbefattet i privilegierne. Det var jo netop Dahlmanns kongstanke, at landet kun kunne få en forfatning ved, at ridderskabet hævdede sine privilegier. Regeringens svar var et rentekammerpatent af 8. marts 1817, hvori der truedes med eksekution, hvis restancer og forfaldne afgifter ikke var betalt inden 14 dage. Af Schows brev af 23. marts fremgår, at Schow kendte forestillingen af 27. januar og vidste, at Dahlmann havde skrevet den. Men Dahl- 
manns konklusioner kan han slet ikke acceptere: „Thi hvis ridderskabets privilegier ikke blot er personlige, men sande landsprivilegier, så er jo grund- og benyttelsesskatten i strid med privilegierne blevet pålagt hele landet" (og ikke blot ridderskabet). Og, fortsætter Schow, hvordan kan skattebevillingsretten tilstås et enkelt korps? Vil regeringen ikke blot blive forbitret, så at der intet udrettes for landet? Schow tilråder, at ingen af parterne sætter sagen på spidsen, men bag dette råd skjuler sig i virkeligheden hans fuldstændige uenighed med Dahlmanns politiske linje. "Thi hvad skal regeringen stille op?" spørger han. Den kan ikke opfylde ridderskabets ønsker "uden at gøre hele det øvrige land uret". Tanken om, at godsejerne slutter sig sammen for i fællesskab at bære eksekutionsbyrderne, er ham modbydelig. Aftalen „er åbenbar opposition mod landherrens befalinger og hæmmende for al regeringsmyndighed. En sådan tilstand fører imidlertid til anarki, og dette er endnu skrækkeligere end despoti.“

I disse ord åbner sig den dybe kløft, der adskilte Dahlmann fra Schow og hans venner. For nationalromantikeren Dahlmann var opgaven at genoplive den gamle tyske frihed for folkets bedre del gennem et forsvar for adelens gamle privilegier. Den rationalistiske Schow, for hvem nationalisme og tyskhed var begreber fra en fremmed verden, onskede kamp mod enevælden ("despotiet“), støttet til borgerskabet og $i$ dets interesse. Han kunne lade sig rive med af Dahlmanns tankeflugt, og han beundrede Dahlmann som menneske og som skribent, men af Dahlmanns hele konception tilegnede han sig kun den retshistoriske argumentation, som kunne bruges til at underbygge borgernes angreb på enevælden. „Hvor længe vil de nuværende magthavere kunne holde stand over for et frit, åndeligt virksomt folk?" lyder en karakteristisk sætning med revolutionære efterklange i Schows brev af 23. marts.

Gennemgangen af Schows breve til Dahlmann har vist, at de slesvigske byers forfatningspetitioner var udtryk for en selvstændig politisk aktion af borgerligt liberalt præg og med tyngdepunkt i det nordlige Sønderjylland. Ønsket om en begrænsning af enevælden har selvfølgelig ulmet længe i borgerskabet, men det er blevet aktualiseret af den økonomiske og politiske katastrofesituation i monarkiet, af de kielske liberales hævdelse af gamle forfatningsrettigheder og af indkaldelsen af en forfatningskommission 
for Holsten. For at gøre Slesvigs parallelle forfatningsønsker gældende pålagde nu en kreds af liberale Dahlmanns ven Schow at undersøge muligheden for at lade dette ske $i$ samarbejde med ridderskabet. Man tør antage, at det er Schow, der har anbefalet denne fremgangsmåde, fordi byerne ellers ikke kunne få et legalt "foreningspunkt", og at han med dette argument har sikret dens vedtagelse til trods for hele kredsens dybt indgroede skepsis til adelens bestræbelser. Da ridderskabet og Dahlmann ganske afslår at tage sig af byernes sag, beslutter de slesvigske liberale at optræde på egen hånd. Deres vejleder bliver ikke Dahlmann, men en kongetro, holstensk embedsmand, baron Brockdorff, der råder til at betone rent praktiske hensyn og lade de tvivlsomme retsdeduktioner fare. Afgørende for bykollegiernes tilslutning til planen var Flensborgs holdning; så snart Flensborg gik med, fulgte de andre efter. Samtidig var det forbi med tanken om et samarbejde mellem byerne og ridderskabet; da Schow igen bragte den på bane, fandt han ingen støtte hos sine meningsfæller.

De Schow'ske breve nødvendiggor også en omvurdering af Dahlmanns politiske ståsted i forfatningsbestræbelserne. Brevene viser ikke alene, at Dahlmann ingen direkte andel havde $i$ den slesvigske forfatningsaktions opståen, men også, at han misbilligede selve aktionen. Hildet $\mathrm{i}$ et romantisk historiesyn troede han, at kun genoplivelsen af adelens privilegier $\mathbf{i}$ deres gamle omfang kunne skaffe Hertugdømmerne en forfatning. Han førte derved den liberale bevægelse, hvis naturlige basis fandtes $i$ borgerskabet, ind på et vildspor.

\section{NOTER}

1. Dette synspunkt finder man f. eks. hos de to Dahlmann-beundrere Otto Scheel (Der junge Dahlmann. 1926) og Carl Petersen (Nicolaus Falck und die Entstehung des schleswig-holsteinischen Gedankens. 1926).

2. 1. bind, s. $139 \mathrm{f}$.

3. sum nicht den gewaltsamen Sinn der Regierung zu reizen «.

4. Hos Springer en trykfejl: Stände.

5. Jeg udtaler min bedste tak til dr. Lülfing, lederen af Deutsche Staatsbibliotheks håndskrifts- og inkunabelafdeling, som elskværdigt har ladet brevene mikrofotografere. Foruden de nedenfor behandlede breve har Dahlmanns arkiv yderligere rummet et brev 
fra Schow, dateret 14. 4. 1834, men kassen med dette brev er forsvundet under 2. verdenskrig. Koncepter til Dahlmanns breve til Schow findes ikke i Dahlmann-arkivet, og det må derfor antages, at Springer alene har bygget sin fremstilling på Schows breve.

6. Således beslutningen om skattenægtelse i 1817; se Dahlmanns brev til Rühs hos Springer I, s. 142.

7. Om ridderskabets politik $i$ disse år se navnlig J. S. M. Ostenfeld: Studier over Stemninger og Tilstande i Holsten (1815-30). 1909.

8. S. 207, note 27. 